to draw a further distinction between a previable and a viable fetus. The first is one which is unable to function as a self-sustaining whole independently of the mother," whereas the viable fetus is able to do that. And the Group recommends that 20 weeks rather than the traditional 28 weeks should be taken as the dividing line between the two - that is, as prima facie proof of viability.

The use of fetal tissues has long been necessary in virology, cancer research, immunology, and other work, and research with the whole, previable fetus is conducted to study development and deformity among other things. Even at this stage stringent precautions are needed to ensure that such studies are ethical, necessary, and likely to be informative. The Group therefore recommends that the fetuses used must weigh less than $300 \mathrm{~g}$, that whether a particular fetus is used must rest with the medical attendants at its birth and not with the intending research worker, and that the research should be carried out in departments directly related to a hospital and only with the sanction of its ethical committee.

Research on a viable fetus is an entirely different matter. There can be no doubt of an overriding ethical obligation to sustain its life. As the report says, "it is both unethical and illegal to carry out any experiments on it which are inconsistent with treatment necessary to promote its life, although in many instances the techniques used to aid a distressed fetus are so new that they are in some degree experimental."

When Mr. Norman St. John-Stevas, M.P., declared in May 1970 that aborted live fetuses had been sold for medical experiments ${ }^{2}$ he was raising the temperature of an already rather feverish subject, and it is regrettable that his name is not among those of the individuals who submitted evidence to the Advisory Group, though the Group was set up as a direct consequence of his allegations. Its Report expresses the general opinion of the medical profession in condemning the buying and selling of fetuses, for any traffic of this kind would be obnoxious to doctors. And the concern it expresses throughout for the observance of impeccable standards of ethics is a valuable reminder that the fetus is a potential human being - a patient, not an experimental animal. 1 Advisory Group (Chairman, Sir John Peel), The Use of Fetuses and

2 British Medical fournal, 1970, 2, 433.

\section{Choices in Science}

The immediate reaction of the scientific community to the report $^{1}$ of the Select Committee on Science and Technology has been one of relief. Mr. Airey Neave's committee has effectively demolished Lord Rothschild's proposals, ${ }^{2-4}$ admonished the Government for prejudging the issue, and virtually guaranteed that the present research council system will not be significantly disturbed until a detailed review has been made. Now that the immediate threat to their interests has been averted most scientists seem only too glad to get back to their laboratories and leave further argument to the politicians.

This attitude is short-sighted, for a major issue has been raised by the select committee: who should decide the choice of objectives for Government-financed research?
The answer to this question is likely to be settled when the Government publishes its White Paper on research later this summer. At present, as the committee pointed out, there are "no adequate machinery and no criteria for decisions on national priorities for research and development." The allocation of research grants by the scientific research councils has undoubtedly been based on careful and dispassionate assessment of the merits of proposals put up to them, but no person or body seems to have had the responsibility for identifying problems of national importance and arranging for research to be done in an attempt to solve them. When Mr. Airey Neave's committee asked the Medical Research Council what was being done about backache it clearly thought the answer less than satisfactory.

It can be argued that the scientists do not respond well to direction, and that only in wartime is it possible to pressgang top-grade research workers into working on problems that are not their primary interests. Furthermore, many scientists have a reasonable suspicion of decisions made by committees, and particularly Government committees. Nevertheless, the intellectual independence claimed by research scientists as the indispensable condition of success in their work is largely financed nowadays, outside the industrial companies, from general taxation, and it is natural for the taxpayers to hope for some return from it. They are asking in other words that research should at least be directed to ends that will benefit the community, while recognizing that something unexpected may turn up on the way. It is against this background that the select committee proposed setting up a 12-man council for science and technology, chaired by a cabinet minister responsible for all Government research. Sources at Westminster regard the chances of a minister being appointed as slight, though the council might have a better chance of Government approval. Such a council may not be a perfect way of giving the community a bigger voice in Government spending on research, but it seems a reasonable proposal and one that should be given a fair trial.

\footnotetext{
1 Select Committee on Science and Technology, First Report, Research and Develooment. London, H.M.S.O.. 1972.

2 A Framework for Government Research and Development. London, H.M.S.O.. 1971.

3 British Medical fournal, 1971, 4, 576.

4 British Medical fournal, 1972, 1, 323.
}

\section{Replantation of the Foot}

Replantation of severed limbs has always provided a challenge to surgeons who have the necessary skill, though it must be admitted that the results are not wholly satisfactory. Animal experimentation showed the feasibility of replantation as long ago as 1903,1 but the first successful human operation was performed on the upper limb in 1964 by R. A. Malt and C. F. McKann. ${ }^{2}$ The first successful replantation of the lower limb was performed by $H$. R. Magee and W. R. Parker in 1969.3

The principles involved seem now to be well established. The time lapse between injury and operation should be less than six hours. There should not be any possibility of other internal injuries, because anticoagulation measures can precipitate fatal haemorrhage from an otherwise benign intraabdominal (or thoracic or cranial) injury. The severed part 
of the limb should be cooled until the operation takes place. The more cleanly severed the amputation the better the chance of success. Thus, crushing wounds and severe contamination are contraindications at present. Two surgical teams are necessary to prepare both sides with prompt efficiency to minimize the risk of infection. Limb shortening is necessary to ensure accurate repair of vessels and nerves and adequate fixation of skeletal structures.

Magee and Parker point out that lower limb replantation carries with it a complication which is not troublesome in upper limb replants. Mobilization of the patient with resultant dependency of the repaired leg is accompanied by venous stasis and oedema, and therefore prolonged recumbency is necessary. In their patient residual oedema was still present five months after operation. The adequacy of the circulation in this case can be judged by the fact that the hallux became gangrenous and was amputated at the end of the thirteenth week. The most important criterion of success (which is the same as in the upper limb) is the degree of recovery in the peripheral nerves. In Magee and Parker's patient some skin sensitivity was recovered as far forward as the metatarsal heads, the toes remaining anaesthetic and immobile. This meant that driving a car with foot pedals was possible.

Whether replantation of a lower limb is justifiable remains debatable at present. The surgical team must consider the patient as an individual, including his psychological makeup and his way of life as well as his physical state. A labourer subjecting his feet to hard wear and severe climatic conditions would probably fare better with an artificial limb. A sedentary worker with some disability in the other leg might be enthusiastic about the possibility of a fair result from replantation.

Modern developments in vascular repair with the help of anticoagulant and antibiotic therapy should lead to better results. There will be at least a few suitable opportunities for this procedure during the lifetime of surgeons engaged in accident surgery. Successful results are more probable if surgeons are aware of the possibilities and work out advance plans with their colleagues to make the best of an opportunity when it comes, as it may, unexpectedly.

1 Höpfner, E., Archiv für klinische Chirurgie, 1903, 70, 417.

Malt, R. A., and McKann, C. F., Fournal of the American Medical Associa-

tion, 1964, 189, 716.
3agee, H. R., and Parker, W. R., Medical fournal of Australia, 1972, 1, 751 .

\section{Pneumoconiosis Redefined}

In 1950 the Third International Conference of Experts on Pneumoconiosis, held in Sydney by the International Labour Office (I.L.O.), defined pneumoconiosis as "a diagnosable disease of the lungs produced by the inhalation of dust, the term dust being understood to refer to particulate matter in the solid phase but excluding living organisms."1 A classification of radiographs based on the distinction between discrete opacities and coalescent shadows was made to promote mutual understanding between scientists rather than as a legal basis for compensation.

The Fourth International Conference met last year in Bucharest, and the Working Group convened there for the purpose by I.L.O. redefined pneumoconiosis as "the accumulation of dust in the lungs and the tissue reactions to its presence."2 Dust was now taken to mean "an aerosol composed of solid inanimate particles."

The Working Group considered that the tissue reactions concerned fall into two categories. Firstly, there is noncollagenous pneumoconiosis, in which the stromal reaction is minimal and consists mainly of reticulin fibres; the alveolar architecture remains intact, and the lesions are potentially reversible. Non-fibrogenic dusts such as those of tin oxide and barium sulphate arouse this type of response. Secondly, collagenous pneumoconiosis with permanent scarring may be caused by fibrogenic dust such as silica or asbestos, or by an altered tissue response to a non-fibrogenic dust. Complicated coalworker's pneumoconiosis or progressive massive fibrosis is an example of such an altered response.

The definition has therefore become one of morbid anatomy. This implies that, as in the case of emphysema, though clinical, radiological, and physiological techniques contribute, the diagnosis is not complete until the lungs have been obtained for morbid anatomical examination.

The Working Group also mentioned the recognition since 1950 of occupational chronic pulmonary diseases which, though they develop from the inhalation of dust, are excluded from the pneumoconioses because particles are not known to accumulate in the lungs. These include byssinosis, berylliosis, and the many varieties of extrinsic allergic alveolitis, of which farmer's lung is the archetype. The tissue reaction is characterized by granulomata, and if the bronchial tissue responds there is apt to be bronchial constriction.

The 1950 classification of radiographs was replaced in 1958 by the "Geneva classification," 3 whch was itself revised in 1968.4 The new classification was needed to accommodate the new pneumoconioses which were added to those of silica and coal. It includes a simple scheme suitable for assessing individual cases and an expanded one for surveys. The standard set of $x$-rays is essential and is available for $\mathbf{3 0}$ U.S. dollars. ${ }^{5}$ The place of pulmonary function tests in pneumoconiosis was reviewed by the I.L.O. in $1966 .{ }^{6}$

Deaths from pneumoconiosis in Great Britain remain at about 900 per year, ${ }^{7}$ but approximately 10,000 of the 280,000 coal miners receive benefit for respiratory disability attributed to their work by the Pneumoconiosis Medical Panels. However, the proportion of claimants who are not coal miners is rising and has now reached $10 \%$. The situation in Britain with regard to protection, detection, and compensation is probably better than in many of the countries we shall be joining in the European Economic Community, though comparable data are not available. The International Labour Office in Geneva occupies an ideal position from which to stimulate further study of biological responses to inhaled material in the enlarged Community so that detection and treatment may be improved and sensible and effective protective measures properly tested and universally applied, for each new case of pneumoconiosis represents an avoidable individual tragedy.

1 The Third International Conference of Experts on Pneumoconiosis, Report of Proceedings. Geneva, I.L.O., 1953.

2 The Fourth International Pneumoconiosis Conference: Working Party on the Definition of Pneumoconiosis, Report. Geneva, I.L.O., 1971.

3 Meeting of Experts on the International Classification of Radiographs of the Pneumoconioses, Occupational Safety and Health, 9, 63. Geneva, I.L.O., 1959

International Classification of Radiographs of Pneumoconioses (Revised 1968): Occudational Safetv and Health Series No. 22. Geneva, I.L.O., 1970.

5 Elmes, P. C., British fournal of Industrial Medicine, 1971, 28, 93.

Respiratorv Function Tests in Pneumoconioses: Occupational Safety and Health Series No. 6. Geneva, I.L.O., 1966.

' Department of Trade and Industrv, Digest of Pneumoconiosis Statistics, 1970, p. 9. London, H.M.S.O., 1972.

(I.L.O. publications are obtainable from the I.L.O. office at 40 Piccadilly, London W.1.) 